\title{
Induction of growth arrest in colorectal cancer cells by cold plasma and gold nanoparticles
}

\author{
Shiva Irani ${ }^{1}$, Zhohreh Shahmirani ${ }^{1}$, Seyed Mohammad Atyabi ${ }^{2}$, Shahriar Mirpoor ${ }^{3}$
}

\author{
'Department of Biology, Science and Research Branch, Islamic Azad University, \\ Tehran, Iran \\ 2Department of Pilot Biotechnology, Pasteur Institute of Iran, Tehran, Iran \\ ${ }^{3}$ Department of Plasma, Shahid Beheshti University, Tehran, Iran
}

Submitted: 16 August 2013

Accepted: 17 December 2013

Arch Med Sci 2015; 11, 6: 1286-1295

DOI: $10.5114 /$ aoms.2015.48221

Copyright $\odot 2015$ Termedia \& Banach

\section{Abstract}

Introduction: Guided treatments with nanoparticles and cold atmospheric plasma are a new approach in cancer therapy. Plasma is an ionized gas that has reactive and energetic particles and can be produced in the laboratory by different methods.

Material and methods: Plasma jet therapy was employed to irradiate HCT116 cells (human colorectal cancer cells) which were cultured in the presence of gold nanoparticles (GNPs). Cell cytotoxicity was tested with 3-[4, 5-dimethylthiazol-2-yl]-2,5 diphenyltetrazolium bromide (MTT), and cancerous cell apoptosis was shown by 4',6-diamidino-2-phenylindole (DAPI) staining. Results: The results showed that cell death was increased significantly with $p<0.001$ by cold atmospheric plasma in the presence of gold nanoparticles. Conclusions: It appears that non-thermal plasma and gold nanoparticles synergism is a promising approach in colon cancer therapy.

Key words: nanoparticles, non-thermal plasma, colorectal cancer.

\section{Introduction}

Today, cancer is one of the major health problems throughout the world. Carcinoma is the most prevalent type of cancer, originating in epithelial cells. One of the most important types of carcinoma is colorectal cancer, which is the third leading cause of death worldwide [1-4]. Treatments such as chemotherapy and radiation can be very expensive and have side effects such as burns, nausea and so on, plus they strongly affect the normal cells. In recent years, new methods and specific courses of action of this treatment have been developed to reduce these side effects. Cancer cell treatment with nanoparticles and cold atmospheric plasma is a new approach for cancer therapy. Plasma, subdivided into thermal and non-thermal (cold plasma), is an ionized gas that has reactive and energetic particles such as positive and negative ions, electrons, metastables, atoms, free radicals and photons [5].

Cold plasma is generated by an electric discharge. The plasma produced through this method is not thermodynamically stable and it is called "cold plasma" because the electron temperature is much higher than heavy species. Electron temperatures reach up to $10^{4}-10^{5} \mathrm{~K}$ while the gas temperature remains at about room temperature [6]. Cold plas-

\author{
Corresponding author: \\ Seyed Mohammad Atyabi PhD \\ Department \\ of Pilot Biotechnology \\ Pasteur Institute of Iran \\ No. 358, 12th Farwardin Ave \\ Jomhhoori St, 3159915111 \\ Tehran, Iran \\ Phone: +98 2166953311 \\ E-mail: mohammadatyabi@ \\ yahoo.com, \\ atyabi@pasteur.ac.ir
}


ma can be produced under atmospheric pressure and can be generated from the production of inert gases such as argon and helium for the production of stable plasma. When a molecular gas such as oxygen is added to inert gas, active species such as reactive oxygen species (ROS) and reactive nitrogen species (RNS) are simultaneously generated. Cold atmospheric plasma can react with an organic surface without any thermal and electrical damage and does not cause any toxic effect on the surrounding cells [7, 8]. Cold atmospheric plasma can change intracellular biochemical signaling pathways and triggers many events in living tissues and organisms. These features and non-equilibrium specifics and active species generation need no expensive or large vacuum reactors, thus making non-thermal plasma very attractive for medical application, for example: sterilization of living and non-living surfaces [8-10], gene transfection [11-13], surgery [14], cell detachment [15-18], growth factor release induced cell proliferation [10], wound healing [19], blood coagulation $[9,20,21]$, and treatment of skin disease [7, 9, 22-24]. One of the most important applications of cold plasma is the induction of apoptosis in cancer cells $[8,25]$, which more or less acts selectively and does not affect normal cells [26].

Recently researchers have made use of nanotechnology for enhancement of the effects of cold plasma.

Recent advances in nanotechnology have resulted in the use of nanoparticles such as gold nanoparticles, which have found application in biomedical and biological fields. Gold nanoparticles are chemically inert and can be produced easily in different sizes and shapes and with different functionalized surfaces [27]. Due to the features of gold nanoparticles such as the resonance plasmon surface, the strong scattering and absorption of light, biocompatibility and safety, they have been approved by the American Food and Drug administration and are now used in photothermal therapy, diagnosis, drug delivery and cancer therapy [28-31]. One of the effects of gold nanoparticles is the induction of apoptosis in cancer cells, acting more or less selectively and not affecting normal cells.

This investigation was performed to study the effect of cold plasma in presence of gold nanoparticles on the induction of apoptosis in colon cancer cells (HCT-116 cell line).

Plasma jet configurations were employed in order to treat the samples. The plasma jet is produced by the induction of an electrical discharge in an insulated nozzle. In this method, cells are not in direct contact with the electrodes, so problems such as electrode corrosion and sample contamination will not occur. In addition, the plasma pro- duced by this method is more uniform in comparison with other methods such as plasma needle and plasma jet with electrode. The average size of the gold nanoparticles was $55.5 \mathrm{~nm}$ in different concentrations of 375, 187.5, 93.7, 46.8 ppm. Cells were treated with oxygen/helium plasma for $40,50,60,90,120$ and $180 \mathrm{~s}$, and the rate of cell death and induction of apoptosis were examined. It is hoped that this therapeutic approach will be effective, cheap and target-oriented in the battle against cancer in reducing the conventional treatment side effects.

\section{Material and methods}

\section{Plasma source}

The plasma jet was made of a Pyrex nozzle tube as an insulating shield (inside diameter (ID) $=2 \mathrm{~mm}$ and outside diameter $(\mathrm{OD})=4 \mathrm{~mm})$. The working gas was fed from the tip of the tube. The inlet gas for this study was helium (99.99\%) with $5 \%$ oxygen as an additional gas to the main feeding gas. $\mathrm{He} / \mathrm{O}_{2}$ was injected into the tube with a flow rate of $2 \mathrm{l} / \mathrm{min}$. A copper electrode with a width of $6 \mathrm{~mm}$ was wrapped around the tube and connected to the power supply. The applied voltage to the electrode ionized the inlet gas fed into the tube and the generated plasma which emitted out from the other end of the tube and propagated about a few centimeters into the ambient air. The power supply produced a $10 \mathrm{kV}$ high voltage pulsing with a frequency of $6 \mathrm{kHz}$ and 30 us pulse width (Figure 1).

\section{Synthesis of gold nanoparticles}

\section{Materials}

$\mathrm{HAuCl}_{4} \cdot 3 \mathrm{H}_{2} \mathrm{O}$ and trisodium citrate used in this study were analytical grade and used without further purification. All glassware was cleaned in aqua regia (4 part $\mathrm{HCl}, 0.5$ part $\mathrm{HNO}_{3}$ ), rinsed with sonication and nanopure $\mathrm{H}_{2} \mathrm{O}$ and then oven dried prior to use.

\section{GNPs preparation}

Gold nanoparticles (GNPs) were prepared by the citrate reduction of $\mathrm{HAuCl}_{4} \cdot 3 \mathrm{H}_{2} \mathrm{O}$ following the methods of Strohoff et al. A volume of $50 \mathrm{ml}$ of $38.3 \mathrm{mM}$ trisodium citrate solution was added quickly at once to a magnetically stirred boiling aqueous solution of $\mathrm{HAuCl}_{4}(1 \mathrm{mM}, 500 \mu \mathrm{l})$, resulting in a change in solution color from pale yellow to deep red. After the color change, the solution was allowed to cool and subsequently filtered through a micron separation of c. $0.45 \mu \mathrm{m}$ nylon filter. Analytical solution of $55 \mathrm{~nm}$ diameter GNPs exhibited a characteristic surface plasmon band centered at $520 \mathrm{~nm}$. The dynamic size was 
A

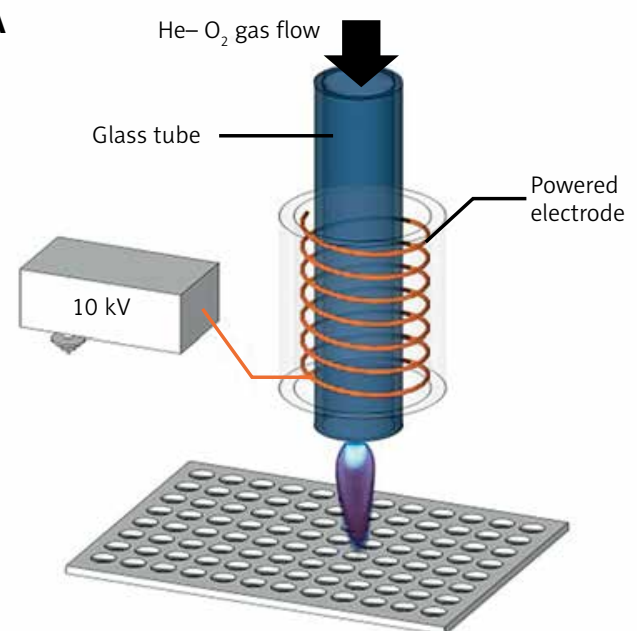



Figure 1. The atmospheric plasma device used in Hct116 carcinoma cell treatment: the plasma jet and the 96-well plate (A); experimental set-up of cold atmospheric plasma and the 96-well plate (B)

measured using a Malvern (Worcestershire, UK). Dynamic light scattering (DLS) measurements of GNPs showed that the nanoparticles had an average hydrodynamic diameter of $56 \mathrm{~nm}$, which was close to the value reported by Strohoff. The same instrument was used to measure the zeta-potential of the gold nanoparticles [32]. From the zeta-potential measurements, it was observed that gold nanoparticles had a negative surface charge $(-3.20 \mathrm{mV})$, which is customarily used in biomedical applications.

\section{Cell line and cell culture}

Human colorectal cancer cells (HCT-116) were purchased from the cell bank of the Pasteur Institute of Iran. The HCT-116 cells were maintained in a high-glucose Dulbecco's modified Eagle medium (DMEM) (Gibco) and were supplemented with $10 \%(\mathrm{v} / \mathrm{v})$ fetal bovine serum (FBS), $100 \mathrm{U} /$ $\mathrm{ml}$ penicillin and $100 \mathrm{mg} / \mathrm{ml}$ streptomycin at $37^{\circ} \mathrm{C}$ in a humidified atmosphere of $5 \% \mathrm{CO}_{2}$. The media were changed every 2 days. After 4-5 days, the cells were removed from the culture flasks by treatment with $0.25 \%$ trypsin/EDTA (ethylenediamine tetraacetic acid) solution, and re-suspended in DMEM-10\% FBS. Viability of cultures was determined by trypan blue exclusion. A volume of $20 \mathrm{ml}$ of HCT-116 cells with media was placed into a microtube, stained with $20 \mathrm{ml}$ of trypan blue and transferred to a hemocytometer slide. The percentage of viable cells was determined by counting the stained and unstained cells.

\section{In vitro plasma treatment}

For plasma cell treatment, the day prior to treatment, HCT- 116 cells were plated at a density of $1 \times 10^{4}$ cells per well in 96 -well plates. The cells were treated with gold nanoparticles at variable concentrations of $375,187.5,93.7$ and $46.8 \mathrm{ppm}$. The smallest number of living cells which had been observed at $375 \mathrm{ppm}$ was treated with helium/oxygen plasma at variable times of 60,90 , 120 and 180 s. Each well of 96-well cluster dishes was placed directly under the nozzle, and the experiment was carried out at room temperature.

\section{Cell viability test}

In this study an MTT assay was employed to determine the viable HCT-116 cell numbers, based on the mitochondrial conversion of the tetrazolium salt 3-[4,5-dimethylthiazol-2-yl]-2,5 diphenyltetrazolium bromide (MTT). The cells were trypsinized, resuspended in DMEM-10\% FBS, counted, carefully seeded at a concentration of $1 \times 10^{4}$ cells per well in 96 wells plate, and were treated with the plasma and gold nanoparticles for different durations. Three wells of a 96-well plate were treated per plasma treatment. After the plasma treatment, the cells were continuously cultured for 24 and $48 \mathrm{~h}$. After these culturing times, the medium was then totally removed and MTT solution ( $5 \mathrm{mg} / \mathrm{ml}$ in PBS) was added into each well of 96-well plate and left to incubate for $4 \mathrm{~h}$ at $37^{\circ} \mathrm{C}$. The MTT reagent was replaced with $100 \mu$ of dimethyl sulfoxide (DMSO) to dissolve the formazan crystals. The optical density of each well was measured at $570 \mathrm{~nm}$ using an ELISA plate reader (BioTek ELx800).

\section{DAPI staining}

A definite number of cells $\left(2 \times 10^{4}\right)$ were seeded per well in a 96-well plate and the cells were simultaneously treated with cold plasma and nanoparticles. Supernatant culture medium was removed after $48 \mathrm{~h}$ and then the cells were washed with phosphate buffered saline (PBS). After washing, 

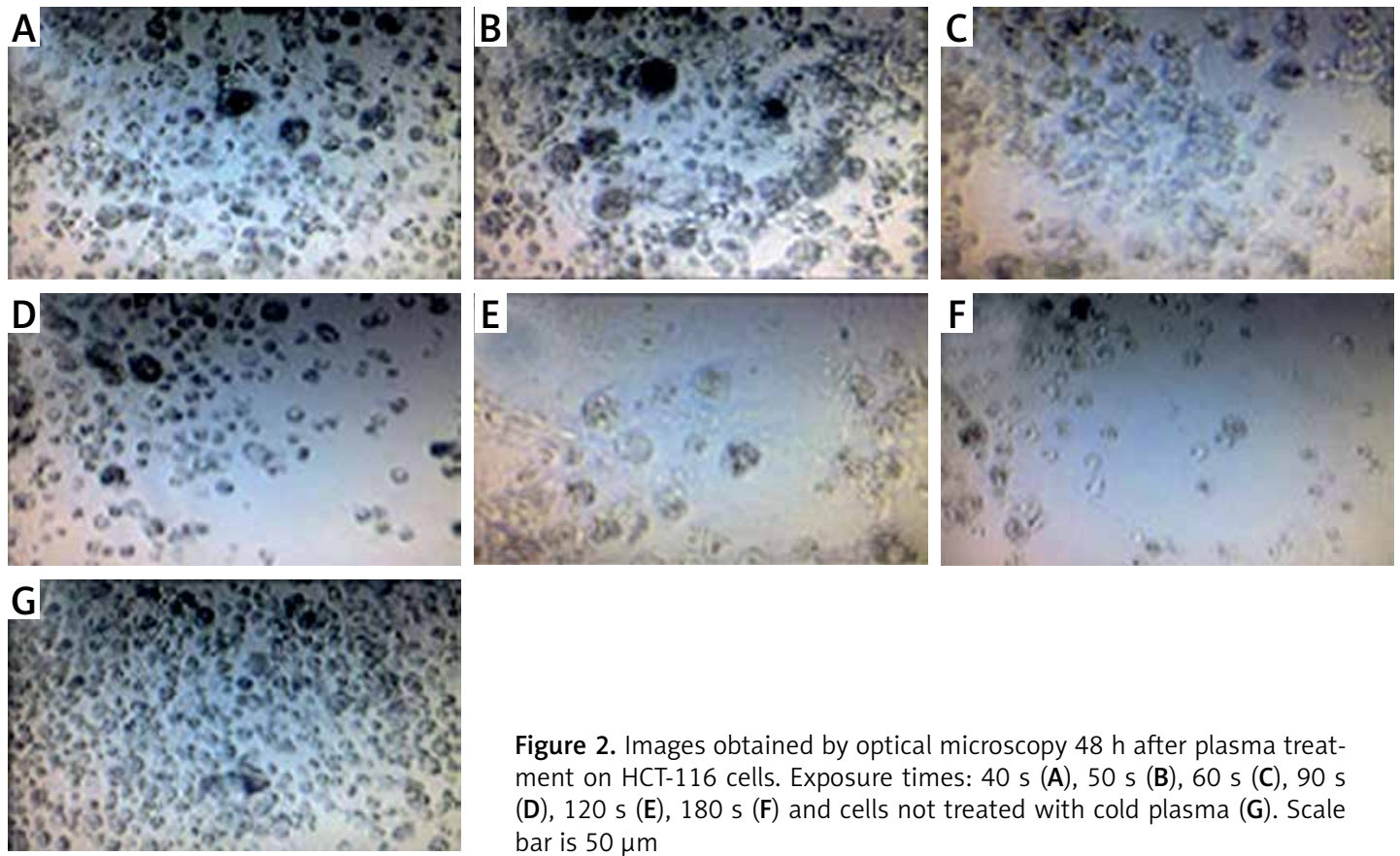

Figure 2. Images obtained by optical microscopy $48 \mathrm{~h}$ after plasma treatment on HCT-116 cells. Exposure times: $40 \mathrm{~s}$ (A), $50 \mathrm{~s}$ (B), $60 \mathrm{~s}$ (C), $90 \mathrm{~s}$ (D), $120 \mathrm{~s}(\mathrm{E}), 180 \mathrm{~s}(\mathrm{~F})$ and cells not treated with cold plasma (G). Scale bar is $50 \mu \mathrm{m}$

a few drops of DAPI were added per well, the plate was incubated for $15 \mathrm{~min}$, then the cells were washed with PBS and observed through a fluorescent microscope.

\section{Annexin V-FITC staining}

Induction of apoptosis by cold plasma and GNP was determined by the Annexin- $v$ Detection kit abCam. After $48 \mathrm{~h}$ of incubation, HCT-116 treated cells were trypsinized, washed with $0.5 \mathrm{ml}$ of cold PBS and suspended with binding buffer. Then, $2 \mu \mathrm{l}$ of Annexin $\mathrm{V}$ were added and incubated at room temperature in the dark for 30 min. Stained cells were analyzed by flow cytometry.

\section{Statistical analysis}

The data were evaluated by a Dunnett one-way analysis of variance (ANOVA) using the software SPSS version 16.0. Then, the a priori $\alpha$ value was set at 0.05 with the level of significance for all statistical analyses $p<0.05$.

\section{Results}

Effect of cold atmospheric plasma on cell viability

The cells were treated with plasma at $10 \mathrm{kV}$ for $40,50,60,90,120$ and $180 \mathrm{~s}$ and proliferated continuously for $24 \mathrm{~h}$ and $48 \mathrm{~h}$.

\section{Cell viability}

Plasma treatment of HCT-116 cells resulted in a significant reduction of cell proliferation after $24 \mathrm{~h}$ and $48 \mathrm{~h}$ treatments (Figure 2).
The effect of the plasma treatment of HCT-116 is shown in Figure 3. The results showed that when HCT-116 cells were treated with cold atmospheric plasma, at increasing exposure time, the number of live cells decreased so that the maximum amount of cell death was observed at $180 \mathrm{~s}$ (Figure 3).

\section{DAPI staining}

Apoptotic cells were detected by staining with DAPI (6-diamidino-2-phenylindole) nuclear staining technique. This technique is known to form fluorescent complexes with double-strand DNA. The apoptotic nuclei (nuclear fragments and condensed chromatin) can be scored in the dying cells by DAPI staining.

The control cells appeared as rounded nuclei and were in a normal state, whereas the cells treated

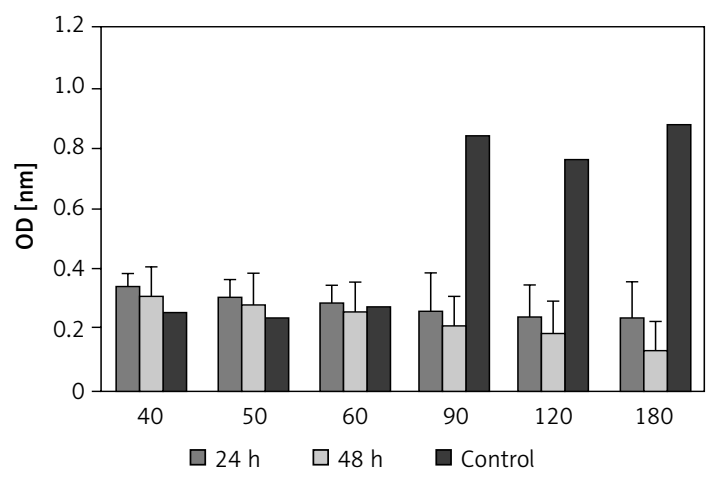

Figure 3. Effect of plasma on viability of HCT 116 cells. Cell viability was determined by MTT assay and was expressed as a mean value \pm standard deviation (SD) of 3 separate experiments. Exposure times: $40,50,60,90,120$ and 180 s. $\rho$-value $=0.000$ 
with cold atmospheric plasma cells appeared with dense nuclei with DNA fragmentation (Figure 4).

\section{Effect of gold nanoparticles on cell viability}

\section{Optical microscopy}

The results of optical microscopy showed the cells being treated with GNPs in different concentrations. When the concentration was increased, the cell viability decreased so that at $375 \mathrm{ppm}$ concentration the smallest amount of living cells was observed, while at 93.7, 46.8 concentrations there were no significant reductions detected in the amount of living cells (Figure 5).

\section{MTT assay after GNP treatment}

The MTT results showed that GNPs with a concentration of 375 ppm have a toxic effect on HCT116 cells, whereas this effect is not observed at low concentration (93.7, 46.8 ppm) (Figure 6).

\section{Effect of GNPs on apoptotic behavior}

The preliminary results from optical microscopy revealed that when HCT- 116 cells were treated with increases in GNPs concentrations, there was a reducing trend in their number of living cells. To show that this reduction is a result of apoptosis, DAPI staining was performed. The control cells and cells that were treated with a low concentration of GNPs (93.7, $46.8 \mathrm{ppm}$ ) had rounded nuclei and were in a normal state. This showed that GNPs with concentrations of 93.7 and 46.8 ppm do not have cytotoxic effects on HCT-116 cells, whereas the cells that were treated with high concentrations of GNPs $(375,187.5$ ppm) showed nuclear condensation and DNA fragmentation, which are manifestations of apoptosis (Figure 7).

\section{Effect of plasma - GNPs on HCT-116 cells}

HCT-116 cells were treated with plasma (exposure time: 60, 90, 120 and 180 s) and were treat-
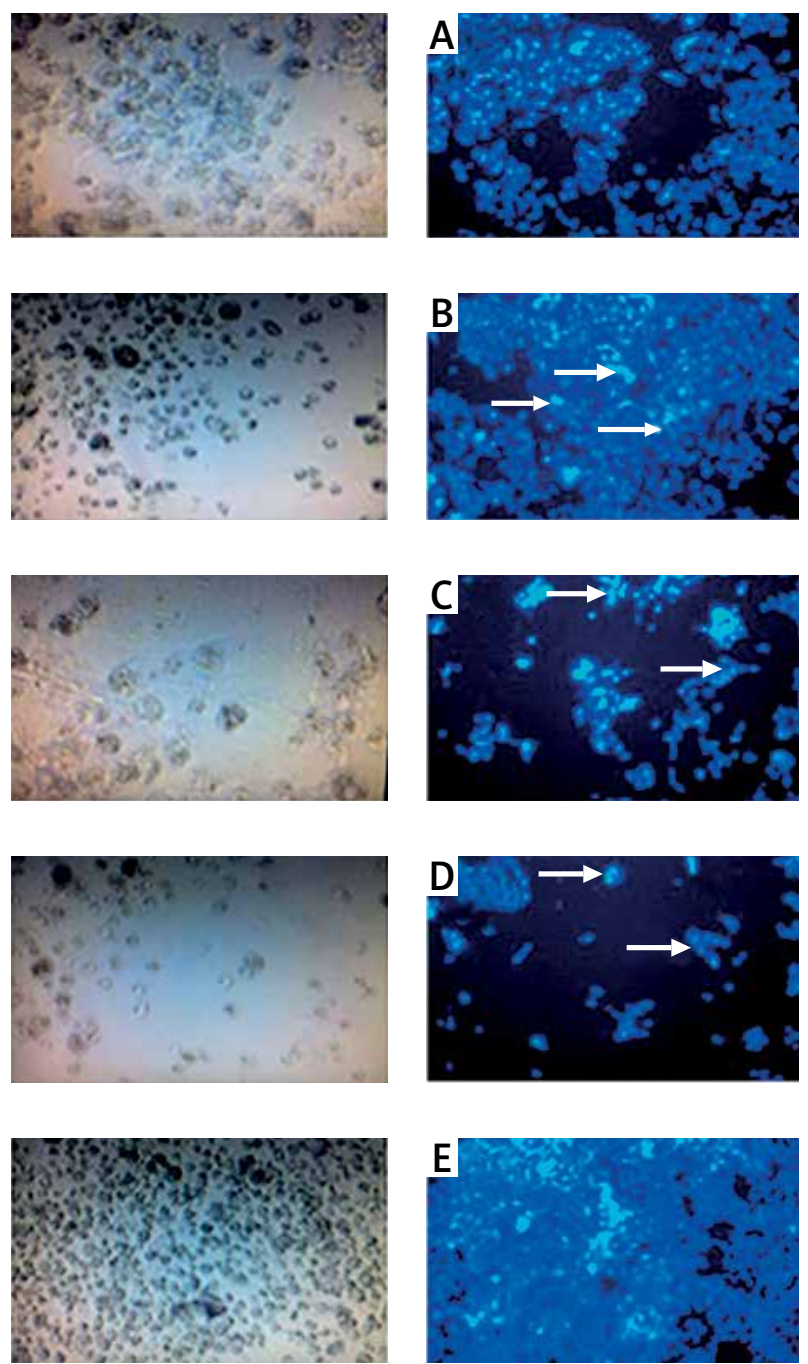

Figure 4. Photographic record of DAPI stained apoptotic cells after plasma treatment on HCT-116 cells. Exposure times: $60 \mathrm{~s}$ (A), $90 \mathrm{~s} \mathrm{(B),} 120 \mathrm{~s}$ (C), $180 \mathrm{~s}$ (D) and cells not treated with cold plasma (E). Scale bar is $50 \mu \mathrm{m}$ 

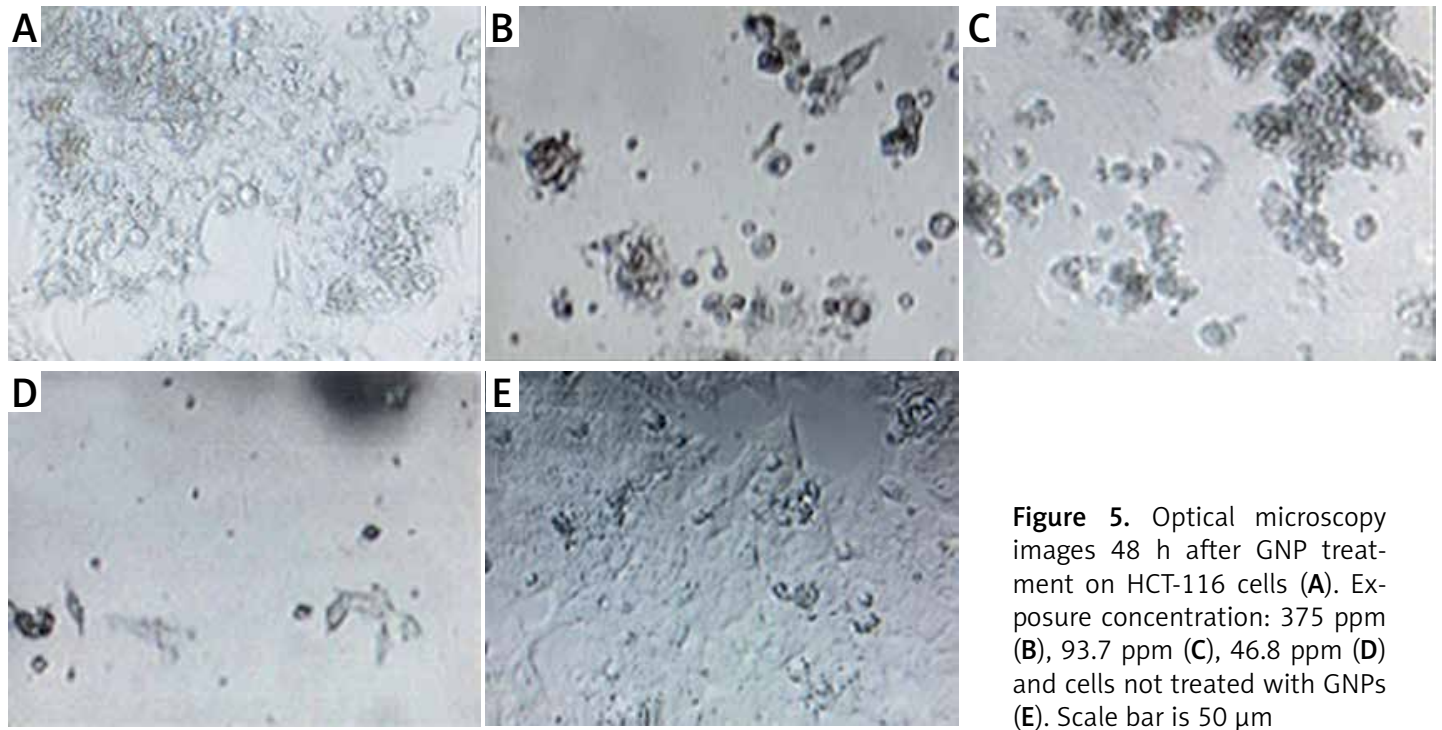

Figure 5. Optical microscopy images $48 \mathrm{~h}$ after GNP treatment on HCT-116 cells (A). Exposure concentration: $375 \mathrm{ppm}$ (B), 93.7 ppm (C), 46.8 ppm (D) and cells not treated with GNPs

(E). Scale bar is $50 \mu \mathrm{m}$

ed with GNPs (375 ppm) and incubated for $24 \mathrm{~h}$ and $48 \mathrm{~h}$.

\section{Optical microscopy}

The results of optical microscopy showed that when the exposure time increased, the number of viable cells was decreased (Figure 8).

\section{MTT assay}

HCT-116 cells were treated with GNPs and cold atmospheric plasma and incubated for $24 \mathrm{~h}$ and $48 \mathrm{~h}$. Then the supernatant was removed and MTT solution was added and incubated for $4 \mathrm{~h}$. Dark-colored crystals were formed. By dissolving these crystals in DMSO solution, light absorption was measured with the ELISA reader (BioTech model). The results showed the cells treated by GNPs and then treated by cold atmospheric plasma. When the plasma treatment time increased, the number of viable cells significantly decreased (Figure 9).

\section{DAPI staining}

To show that apoptotic cell death reduced the number of live cells, DAPI staining was performed. The control cells had rounded nuclei and were in a normal state, whereas the cells treated by GNPs and cold atmospheric plasma showed nuclear condensation and DNA fragmentation, which were manifestations of apoptosis (Figure 10).

\section{Annexin-V staining}

At different levels of non-thermal plasma with GNP, a decrease of viable cells was observed. The cell death induced by non-thermal plasma and GNP was apoptosis. Our data showed that the percentage of apoptotic cells (HCT-116) increased with increasing exposure time of cold plasma (Figure 11).

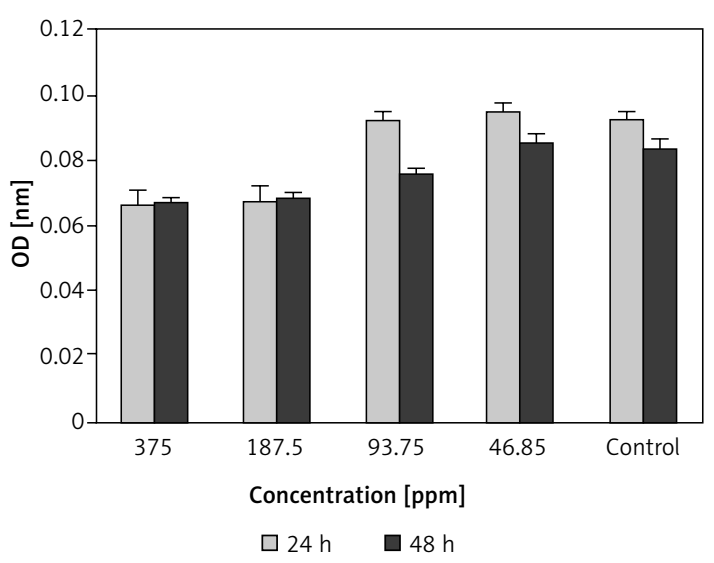

Figure 6. The MTT test results after $24 \mathrm{~h}$ and $48 \mathrm{~h}$ : cells were treated with gold nanoparticles. Gold nanoparticle concentration: 375, 187.5, 93.7 and 46.8 ppm. $\rho$-value $=0.001$

\section{Discussion}

The most important mechanism known for the effect of plasma on live cells and tissues and apoptosis induction is the generation of reactive oxygen and nitrogen. Plasma has energetic electrons. These electrons collide with molecules of oxygen gas and helium gas and air that produce reactive species. The reactive species generated by the plasma include radical species such as hydroxyl radicals, anion superoxides, alkoxyls and nitric oxides, and non-radical species such as hydrogen peroxides, ozone and singlet oxygen. One of the ways and mechanisms of apoptosis activation is DNA damage or lipid peroxidation of cell membrane, which causes programmed cell death. When the ROS generated by plasma attach to DNA, the latter is oxidized by the reactive species, and programmed cell death is activated by ROS, which have an important role in activation of the apoptosis pathway 

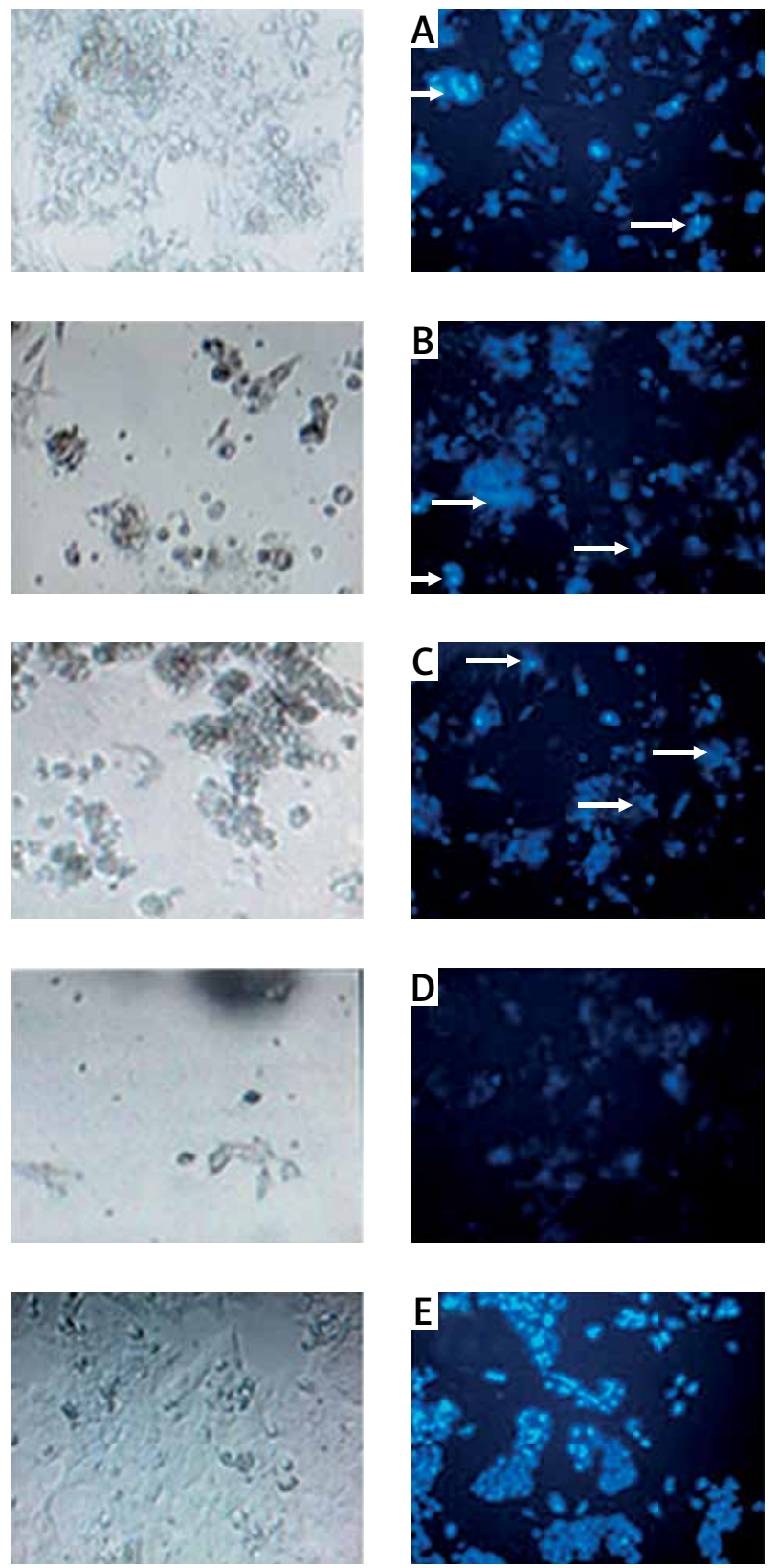

Figure 7. Fluorescence microscopy after DAPI staining $48 \mathrm{~h}$, after GNP treatment on HCT-116 cells. Exposure concentration: 375 ppm (A), 187.5 ppm (B), 93.7 ppm (C), 46.8 ppm (D) and cells not treated with GNPs (E). Scale bar is $50 \mu \mathrm{m}$
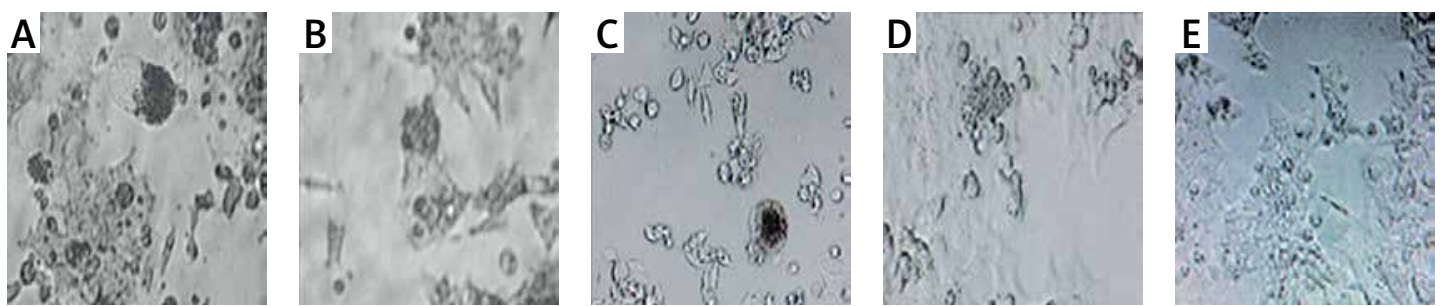

Figure 8. Optical microscopy pictures $48 \mathrm{~h}$ after GNP treatment with $375 \mathrm{ppm}$ concentration and plasma treatment on HCT-116 cells. Exposure times: $60 \mathrm{~s}$ (A), $90 \mathrm{~s}$ (B), $120 \mathrm{~s}$ (C), $180 \mathrm{~s}$ (D) and cells not treated with GNPs and cold plasma (E). Scale bar is $50 \mu \mathrm{m}$

[33]. When the generated plasma for cancer therapy is produced by helium gas only, the percentage of active production is not sufficiently high [25].
With lack of a high percentage of produced active species, the apoptosis pathway will not be activated, and therefore the plasma and action of reactive 
species look like growth factors and activate the cell proliferation pathway. Although the apoptosis mechanism and cell proliferation mechanism are not clearly distinguished, the production of active species is very important to prevent the cells from entering the cell proliferation pathway. Therefore, to increase the percentage of reactive oxygen species in plasma, oxygen gas is added to helium gas.

The gold nanoparticles that were used in this study were $55 \mathrm{~nm}$ with negative zeta potential. Material in nanometer size increases the surface to volume ratio. In this case, the nanoparticles have a tendency to sediment deposition. So to avoid the aggregation phenomena in colloidal systems and prevent electrostatic interactions with the cy-
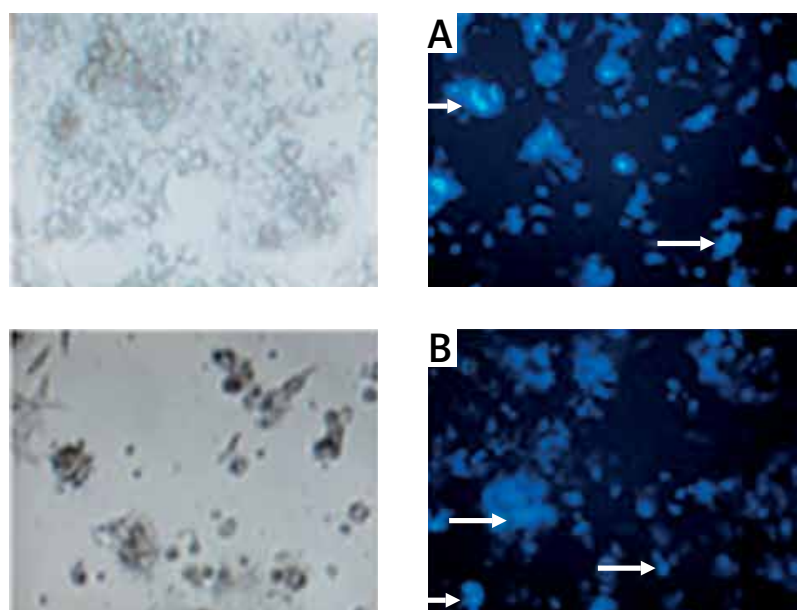

Figure 9. The MTT test results after $48 \mathrm{~h}$ : cells were treated with cold plasma and gold nanoparticles. Gold nanoparticles concentration: $375 \mathrm{ppm}$. Cold plasma exposure time: $60,90,120,180$ s. $\rho$-value $=0.000$


Figure 10. Fluorescence microscopy after DAPI staining $48 \mathrm{~h}$ after GNP treatment with 375 ppm concentration and plasma treatment on HCT-116 cells. Exposure times: $60 \mathrm{~s}(\mathbf{A}), 90 \mathrm{~s}(\mathrm{~B}), 120 \mathrm{~s}(\mathrm{C}), 180 \mathrm{~s}$ (D) and cells not treated with GNPs and cold plasma (E). Scale bar is $50 \mu \mathrm{m}$

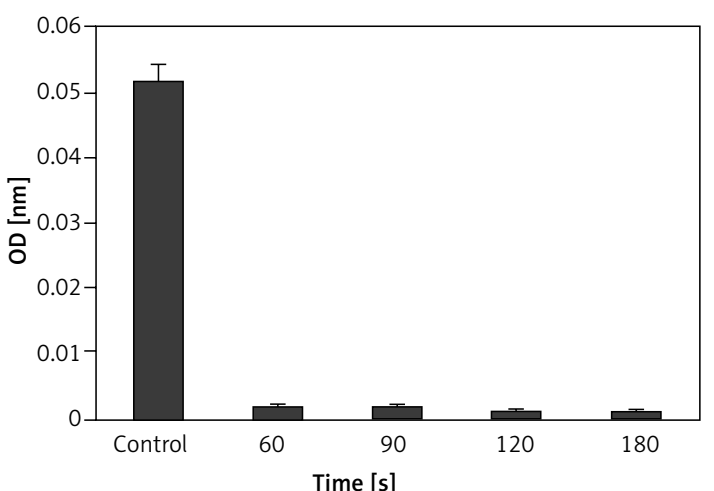






Figure 11. Cell staining with Annexin $V$ for apoptosis detection. Number of viable cells was decreased after treatment with nonthermal plasma and GNPs after $48 \mathrm{~h}$. Gold nanoparticles concentration: 375 ppm, cold plasma exposure time: 60, 90, 120, $180 \mathrm{~s}$

toplasmic membrane and prevent destruction of the cytoplasmic membrane, the zeta potential was selected as negative [34] and the gold nanoparticles were spherical, because these nanoparticles were suitable for a monolayer cell culture and they could easily enter the cells. Nanoparticles in this size selection were unable to pass the nuclear membrane, so they were accumulated around the nucleus in the cytoplasm. Gold nanoparticles have been shown to increase intracellular ROS and also cleave poly (ADP ribose polymerase) [35].

Caspases also cleavage poly (ADP ribose polymerase) and induce apoptosis [36]. Therefore, it seems that GNPs increase the intracellular ROS and cleave poly (ADP ribose polymerase) and induce apoptosis in HCT-116 cells, though the mechanism is not clearly understood. No doubt, the toxicity of GNPs is completely dependent on the size and shape and dosage and also depends on the type of cell [27]. Some researchers who have conducted in vitro tests have shown that GNPs' effect on some cancer cell lines does not show any cytotoxicity. However, in some cancer cell lines they were able to induce apoptosis [35].

In conclusion, in this study the synergy of low-temperature plasma and nanoparticles' effect on HCT-116 cells was investigated, and it was revealed that when HCT-116 cells were treated with GNPs with a concentration of $375 \mathrm{ppm}$ and size of $55 \mathrm{~nm}$ and plasma irradiated for $180 \mathrm{~s}$, it resulted in increased apoptotic cell death, though the mechanism was not clearly understood.

The increase in production of reactive oxygen species may temporarily increase the permeability of cell membrane, which therefore increases the intracellular ROS, finally leading to apoptotic cell death. When plasma and nanoparticles were combined, a number of benefits for the anticancer effects were shown.

\section{Conflict of interest}

The authors declare no conflict of interest.

\section{References}

1. Fakheri H, Janbaba G, Bari Z, Eshqi F. The epidemiologic, clinical and pathologic characteristics of colorectal cancers from 1999 to 2007 in Sari, Iran Persian. Mazandaran Univ Med Sci 2008; 67: 58-6 8.

2. Jobe $A B$, Hunter HG. Minimally-invasive surgery. In: Schwartz principles of surgery. Bruncardi C, et al. (eds.). McGraw-Hill 2005; 386-7, 1089-95.

3. Klimczak A, Kempińska-Mirosławska B, Mik M, Dziki L, Dziki A. Incidence of colorectal cancer in Poland in 1999-2008. Arch Med Sci 2011; 7: 673-8.

4. Smolińska K, Paluszkiewicz P. Risk of colorectal cancer in relation to frequency and total amount of red meat consumption. Systematic review and meta-analysis. Arch Med Sci 2010; 6: 605-10.

5. Fridman A, Chirokov A, Gutsol A. Non-thermal atmospheric pressure discharges. J Phys D: Appl Phys 2005; 38: R1-24.

6. Staack D, Farouk B, Gutsol AF, Fridman A. Spatially resolved temperature measurements of atmospheric-pressure normal glow microplasmas in air. Plasma Sources Sci Technol 2007; 35: 1448-55.

7. Stoffels E, Kieft IE, Sladek REJ, van den Bedem LJM, van der Laan EP, Steinbuch M. Plasma needle for in vivo medical treatment: recent developments and perspectives. Plasma Sources Sci Technol 2006; 15: 169-80.

8. Fridman G, Shereshevsky GA, Jost MM, et al. Floating electrode dielectric barrier discharge plasma in air promoting apoptotic behavior in melanoma skin cancer cell lines. Plasma Chem Plasma Process 2007; 27: 163-76.

9. Fridman G, Peddinghaus M, Ayan H, et al. Blood coagulation and living tissue sterilization by floating-electrode dielectric barrier discharge in air. Plasma Chem Plasma Process 2006; 26: 425-42.

10. Kalghatgi S, Dobrynin D, Fridman G, et al. Applications of non thermal atmospheric pressure plasma in medicine. In: NATO Advanced Study Institute on Plasma Assisted Decontamination of Biological and Chemical Agents. Springer, Cesme-Izmir, Turkey 2008; 173-83.

11. Leveille V, Coulombe S. Design and preliminary characterization of a miniature pulsed RF APGD torch with downstream injection of the source of reactive species. Plasma Sources Sci Technol 2005; 14: 467-77.

12. Coulombe S, Léveillé V, Yonson S, Leask RL. Miniature atmospheric pressure glow discharge torch (APGD-t) for local biomedical applications. Pure Appl Chem 2006; 78: 1147-56.

13. Coulombe S. Live cell permeabilization using the APGD-t. First International Conference on Plasma Medicine (ICPM-1)", Corpus Christi, Texas 2007.

14. Priglinger SG, Haritoglou C, Palanker DV, Alge CS, Gandorfer A, Kampik A. Pulsed electron avalanche knife (PEAK-fc) for dissection of retinal tissue. Arch Ophthalmol 2005; 123: 1412-8.

15. Stoffels E, Kieft IE, Sladek REJ. Superficial treatment of mammalian cells using plasma needle. J Phys D: Appl Phys 2003; 36: 2908.

16. Kieft IE, Broers JLV, Caubet-Hilloutou V, Slaaf DW, Ramaekers FCS, Stoffels E. Electric discharge plasmas influence attachment of cultured CHO K1 cells. Bioelectromagnetics 2004; 25: 362-8. 
17. Kieft IE, Darios D, Roks AJM, Stoffels E. Plasma treatment of mammalian vascular cells. IEEE Trans Plasma Sci 2005; 33: 771-5.

18. Kieft IE, Kurdi M, Stoffels E. Reattachment and apoptosis after plasma-needle treatment of cultured cells. IEEE Trans Plasma Sci 2006; 34: 1331-6.

19. Lloyd G, Friedman G, Jafri S, Schultz G, Fridman A, Harding K. Gas plasma: medical uses and developments in wound care. Plasma Process Polym 2010; 7: 194-211.

20. Gaunt LF, Beggs CB, Georghiou GE. Bactericidal action of the reactive species produced by gas-discharge nonthermal plasma at atmospheric pressure: a review. IEEE Trans Plasma Sci 2006; 34: 1257-69.

21. Moisan M, Barbeau J, Moreau S, Pelletier J, Tabrizian M, Yahia L. Low-temperature sterilization using gas plasmas: a review of the experiments and an analysis of the inactivation mechanisms. Int J Pharmaceutics 2001; 226: 1-21.

22. Fridman G, Sheterkh AB, Vesilets VN, Fridman G, Ustol AG, Fridman A. Applied plasma medicine, plasma process. Polymer 2008; 5: 503-33.

23. Reshetov IV, Kabisov RK, Shekhter AB, Pekshev AV, Maneilova MV. The application of a air-plasma apparatus "Plason" in the regimes of coagulation and NO-therapy with the plastic-reconstruction operations in oncologic patients. Ann Plastic, Reconstruct Aesthet Surg 2000; 4: 24-39.

24. Shekhter AB, Serezhenkov VA, Roudenko TG, Pekshev AV, Vanin AF. Beneficial effect of gaseous nitric oxide on the healing of skin wounds. 2005; 12: 210-9.

25. Kim E, Bahn J, Lee $S$, et al. Induction of cell growth arrest by atmospheric non-thermal plasma in colorectal cancer cells. J Biotechnol 2010; 150: 530-8.

26. Dobrynin D, FridmanG, Friedman G, Fridman A. Physical and biological mechanisms of direct plasma interaction with living tissue. New Journal of Physics 2009; 11: 115020-46.

27. Lewinski N, Colvin V, Drezek R. Cytotoxicity of nanoparticles. Small 2008; 4: 26-49.

28. Jain PK, Huang XH, El-Sayed IH, El-Sayed MA. Noble metals on the Nanoscale: optical and photothermal properties and some applications in imaging, sensing, biology, and medicine. Acc Chem Res 2008; 41: 1578-86.

29. Lal S, Clare SE, Halas NJ. Nano shell-enabled photo thermal cancer therapy: impending clinical impact. Acc Chem Res 2008; 41: 1842-51.

30. Murphy CJ, Gole AM, Stone JW. Gold nanoparticlesin biology: beyond toxicity to cellular imaging. Acc Chem Res 2008; 41: 1721-30.

31. Skrabalak SE, Chen JY, Sun YG. Gold nanocages: synthesis, properties, and applications. Acc Chem Res 2008; 41: 1587-95.

32. Strohoff JJ, Mirkin CA. Programmed materials synthesis with DNA. Chem Rev 1999; 99: 1849-62.

33. Kim GJ, Kim W, Kim KT, Lee JK. DNA damage and mitochondria dysfunction in cell apoptosis induced by nonthermal air plasma. Appl Phys Lett 2010; 96: 021502-3.

34. Alkilany AM, Murphy CJ. Toxicity and cellular uptake of gold nanoparticles: what we have learned so far? J Nanopart Res 2010; 12: 2313-33.

35. Hirak K, Banerjee S, Chaudhuri U, Lahiri P, Dusgupta A Cell selective response to gold nanoparticles. Nanomedicine 2007; 3: 111-9.

36. Oliver FJ, Rubia G, Rolli V, Ruiz-Ruiz MC, Murica G, Murica JM. Importance of poly(ADP-ribose)polymerase and its cleavage in apoptosis lesson from an uncleavable mutant. J Biol Chem 1998; 273: 33533-9. 